\title{
Influence of the Amazon River discharge on the biogeography of phytoplankton communities in the western tropical north Atlantic
}

\author{
Joaquim I. Goes ${ }^{\mathrm{a}, *}$, Helga do Rosario Gomes ${ }^{\mathrm{a}}$, Alexander M. Chekalyuk ${ }^{\mathrm{a}}$, Edward J. Carpenter ${ }^{\mathrm{b}}$, \\ Joseph P. Montoya ${ }^{c}$, Victoria J. Coles ${ }^{d}$, Patricia L. Yager ${ }^{\mathrm{e}}$, William M. Berelson ${ }^{\mathrm{f}}$, Douglas G. Capone ${ }^{\mathrm{g}}$, \\ Rachel A. Foster ${ }^{h}$, Deborah K. Steinberg ${ }^{i}$, Ajit Subramaniam ${ }^{a}$, Mark A. Hafez ${ }^{\text {a }}$
}

a Lamont Doherty Earth Observatory, Columbia University, Palisades, NY 10964, USA

${ }^{\mathrm{b}}$ Romberg Tiburon Center, San Francisco State University, Tiburon, CA 94920, USA

' School of Biology, Georgia Institute of Technology, Atlanta, GA 30332, USA

${ }^{\mathrm{d}}$ Horn Point Laboratory, University of Maryland Center for Environmental Science, Cambridge, MD 21613, USA

e Department of Marine Sciences, University of Georgia, Athens, GA 30602, USA

${ }^{\mathrm{f}}$ Department of Earth Sciences, University of Southern California, Los Angeles, CA 90089, USA

${ }^{\mathrm{g}}$ Department of Biological Sciences and Wrigley Institute for Environmental Studies, University of Southern California, Los Angeles, CA 90089, USA

${ }^{\mathrm{h}}$ Department of Biogeochemistry, Max Planck Institute for Marine Microbiology, Bremen, Germany

${ }^{\mathrm{i}}$ Virginia Institute of Marine Science, Gloucester Point, VA 23062, USA

\section{A R T I C L E I N F O}

\section{Article history:}

Received 16 October 2012

Received in revised form 11 May 2013

Accepted 22 July 2013

Available online 7 August 2013

\begin{abstract}
A B S T R A C T
An Advanced Laser Fluorometer (ALF) capable of discriminating several phytoplankton pigment types was utilized in conjunction with microscopic data to map the distribution of phytoplankton communities in the Amazon River plume in May-June-2010, when discharge from the river was at its peak. Cluster analysis and Non-metric Multi-Dimensional Scaling (NMDS) helped distinguish three distinct biological communities that separated largely on the basis of salinity gradients across the plume. These three communities included an "estuarine type" comprised of a high biomass mixed population of diatoms, cryptophytes and green-water Synechococcus spp. located upstream of the plume, a "mesohaline type" made up largely of communities of Diatom-Diazotroph Associations (DDAs) and located in the northwestern region of the plume and an "oceanic type" in the oligotrophic waters outside of the plume made up of Trichodesmium and Synechococcus spp. Although salinity appeared to have a substantial influence on the distribution of different phytoplankton groups, ALF and microscopic measurements examined in the context of the hydro-chemical environment of the river plume, helped establish that the phytoplankton community structure and distribution were strongly controlled by inorganic nitrate plus nitrite $\left(\mathrm{NO}_{3}+\mathrm{NO}_{2}\right)$ availability whose concentrations were low throughout the plume. Towards the southern, low-salinity region of the plume, $\mathrm{NO}_{3}+\mathrm{NO}_{2}$ supplied by the onshore flow of subsurface ( $\sim 80 \mathrm{~m}$ depth) water, ensured the continuous sustenance of the mixed phytoplankton bloom. The large drawdown of $\mathrm{SiO}_{3}$ and $\mathrm{PO}_{4}$ associated with this "estuarine type" mixed bloom at a magnitude comparable to that observed for DDAs in the mesohaline waters, leads us to contend that, diatoms, cryptophytes and Synechococcus spp., fueled by the offshore influx of nutrients also play an important role in the cycling of nutrients in the Amazon River plume.
\end{abstract}

(c) 2013 Elsevier Ltd. All rights reserved.

\section{Introduction}

The discharge of freshwater from the Amazon River is the largest of all the world's rivers, and averages around $120,000 \mathrm{~m}^{3} \mathrm{~s}^{-1}$ of freshwater inflow into the Western Tropical North Atlantic (WTNA) Ocean. Since the Amazon River flows through the world's biggest and most densely forested river basins, it carries with it large amounts of sediments, nutrients as well as particulate and Chromophoric Dissolved Organic Material (CDOM) which together,

\footnotetext{
* Corresponding author. Tel.: +1 8452658467.

E-mail address: jig@ldeo.columbia.edu (J.I. Goes).
}

impart a unique color to the discharged water (Del Vecchio and Subramaniam, 2004; Mertes, 1993; Molleri et al., 2010a, 2010b; Nittrouer et al., 1986), making it visible from space as a greenish-brown plume stretching several hundreds of kilometers into the western north Atlantic Ocean (Del Vecchio and Subramaniam, 2004; Hu et al., 2004; Molleri et al., 2010b; Müller-Karger et al., 1989). In summer, when discharge from the river is at its peak, signatures of the plume can be seen as far north as the Caribbean Island chain (Chérubin and Richardson, 2007; Hellweger and Gordon, 2002; Hu et al., 2004; Molleri et al., 2010b).

Although phytoplankton biomass is generally higher within the plume (defined as waters with salinity <35) than in the 
surrounding oceanic waters, the gradient of environmental conditions (light, nutrients, CDOM, salinity, temperature, mixed layer depths, etc.) that evolve (Berhane et al., 1997; Curtin and Legeckis, 1986; Del Vecchio and Subramaniam, 2004; DeMaster, 1996; DeMaster and Pope, 1996; Gibbs, 1976a; Lentz, 1995a, 1995b; Molleri et al., 2010b) as the plume meanders northwards and mixes with the waters of the WTNA Ocean appears to have a profound impact on the magnitude and composition of phytoplankton communities of the Amazon River plume continuum (Carpenter et al., 1999; DeMaster et al., 1986; Santos et al., 2008; Shipe et al., 2006; Smith Jr. and DeMaster, 1996; Wood, 1966). Despite the large amount of nutrients discharged by the river, extremely high concentrations of riverine suspended particles as well as CDOM, restrict the amount of light available for phytoplankton photosynthesis (DeMaster et al., 1983; Smith Jr. and DeMaster, 1996; Smith and Russell, 1995; Teixeira and Tundisi, 1967). As a consequence, phytoplankton biomass accumulation takes place only away from the mouth of the river, when concentrations of riverine suspended material drop to levels low enough to alleviate light limitation of photosynthesis (DeMaster et al., 1983; Smith Jr. and DeMaster, 1996; Smith and Russell, 1995; Teixeira and Tundisi, 1967). Several studies (Smith Jr. and DeMaster, 1996; Teixeira and Tundisi, 1967; Wood, 1966) have shown that diatoms dominate the plume phytoplankton community outside of the mouth of the river. However more recent investigations, undertaken further offshore, have shown that Diatom-Diazotroph Associations (DDAs) belonging primarily to the Genus Hemiaulus dominate phytoplankton communities in the mesohaline (salinity between 30 and 35) waters of the plume (Carpenter et al., 1999; Shipe et al., 2006; Subramaniam et al., 2008) and are responsible for substantial $\mathrm{CO}_{2}$ drawdown $\left(152 \mathrm{mg} \mathrm{m}^{-2} \mathrm{~d}^{-1}\right.$ ) into the WTNA (Cooley and Yager, 2006; Subramaniam et al., 2008; Yeung et al., 2012). Other studies (Capone et al., 2005; Foster et al., 2007; Goering et al., 1966) have alluded to the biogeochemical significance of Trichodesmium erythraeum in the plume. While most of these previous studies have focused on specific phytoplankton types within the plume, studies that provide a comprehensive account of phytoplankton communities across the plume continuum are still lacking.

During the summer (June-July) of 2010 when the discharge from the river was at its peak, we undertook a multi-disciplinary cruise as part of the Amazon iNfluence on the Atlantic: CarbOn export from Nitrogen fixation by DiAtom Symbioses (ANACONDAS) study, to monitor the spatial distribution of phytoplankton communities over a large portion of Amazon River plume continuum. Sampling at fixed stations was greatly aided by additional hourly collections for inorganic nutrients, microscopic analysis of phytoplankton, as well as Advanced Laser Fluorometric (ALF) analysis (Chekalyuk and Hafez, 2008). The ALF is a state-of-the-art instrument, that combines high-resolution spectral measurements of blue $(405 \mathrm{~nm})$ and green $(532 \mathrm{~nm})$ laser-stimulated fluorescence, with spectral deconvolution techniques to estimate CDOM, phytoplankton variable fluorescence $\left(F_{v} / F_{m}\right)$, Chl $a$ and three types of phycobiliprotein pigments. The instrument was connected to the ship's underway seawater intake system to provide continuous real-time measurements or used to analyze samples from discrete depths within the upper water column. Continuous real-time measurements by the ALF provided high resolution spatial distribution patterns of these properties along the ship's cruise track and immensely increased the spatial analysis of phytoplankton groups across the study area.

Here we have examined fluorescence data from the ALF in the context of microscopic data to construct a comprehensive picture of phytoplankton distribution along plume river-ocean continuum. Hydrological, chemical and optical data collected during the cruise and multivariate analytical techniques have been utilized to address questions such as: (1) Is the discharge of freshwater from the Amazon River a significant driver of change in the environment of the WTNA Ocean? (2) Are changes in the hydrological, chemical and optical changes brought about by the interaction of freshwater from the river with oceanic waters significant enough to cause large community changes across the plume? (3) What are the major environmental variables responsible for changes in phytoplankton community structure across the plume?

\section{Materials and methods}

The data presented in this study were obtained on the ANACONDAS-1 cruise undertaken from 22nd May to 25th of June, 2010 in the Amazon River plume on board the R/V Knorr KN1978 (Fig. 1). Seawater samples were obtained from 27 stations within the euphotic zone as well as from the surface, at hourly intervals from Station 9 onwards. The euphotic zone, defined as the depth of $0.1 \%$ irradiance at sea surface, was determined from in-water,

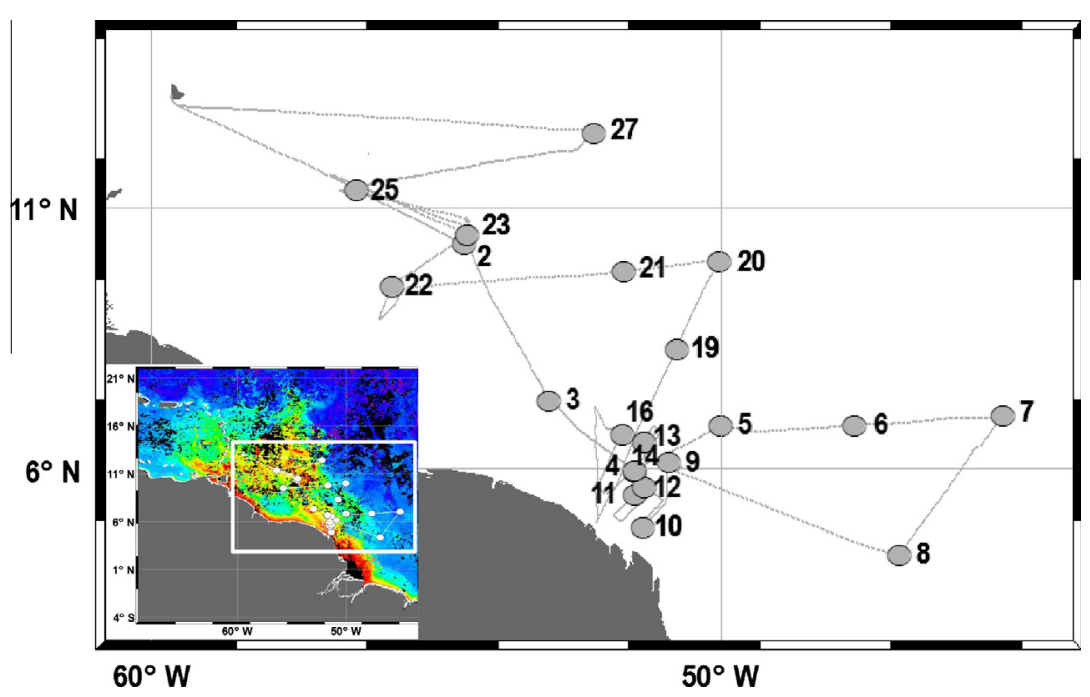

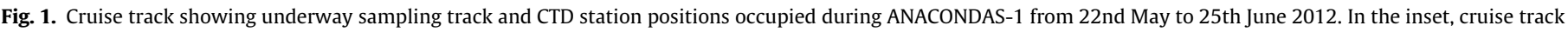
and stations have been overlaid on a monthly composite of MODIS-Aqua Chl $a$ for June 2010 to show the extent of the Amazon River plume. 
profiles of photosynthetically available radiation (PAR) made with a Biospherical Instruments ${ }^{\circledR}$ in-water quantum scalar radiometer at each station. A Conductivity-Temperature-Depth (CTD) Sea-Bird Electronics ${ }^{\circledR}$ Rosette with Niskin bottles was used to sample from six depths, four of which were within the euphotic zone, one within the deep chlorophyll maximum (DCM) and one usually from below the euphotic depth.

Samples for inorganic nutrients $\left(\mathrm{SiO}_{3}, \mathrm{NO}_{3}+\mathrm{NO}_{2}\right.$ and $\left.\mathrm{PO}_{4}\right)$ were collected directly from Niskin bottles attached to a Sea-Bird Electronics $^{\circledR}$ CTD rosette and analyzed immediately onboard using a Lachat ${ }^{\circledR}$ QuikChem 8000 flow-injection analyzer (Knap et al., 1994). At each station, concentrations of phytoplankton including diatoms, dinoflagellates, free trichomes as well as colonies of Trichodesmium spp. and endosymbiotic Richelia intracellularis were determined by filtering 101 of seawater from Niskin bottles onto a $8 \mu \mathrm{m}$ pore size, $47 \mathrm{~mm}$ diameter Nuclepore ${ }^{\circledR}$ filter (Carpenter et al., 1999). Seawater samples were filtered by attaching a Millipore ${ }^{\circledR}$ Swinnex $47 \mathrm{~mm}$ filter holder containing the Nuclepore ${ }^{\circledR}$ filter directly to the spigot of each Niskin bottle. Direct filtration by gravity ensured minimal breakage of individual phytoplankton cells, including chains of diatoms and Trichodesmium colonies, permitting counts of latter as trichomes in colonial- and free-state. Filters were mounted on oversized $(75 \mathrm{~mm} \times 50 \mathrm{~mm} \times 1 \mathrm{~mm})$ glass slides and examined at $400 \mathrm{X}$ under a Zeiss ${ }^{\circledR}$ Axioskop Epifluorescence microscope using green excitation (Carpenter et al., 1999). Diatoms, dinoflagellates, DDAs, trichomes and colonies of Trichodesmium spp., and free and endosymbiotic cells of $R$. intracellularis, were then enumerated on board within $24 \mathrm{~h}$ of collection (Carpenter et al., 1999). Enumeration of Synechococcus spp. cells was undertaken by separately filtering $50 \mathrm{ml}$ seawater on to a $25 \mathrm{~mm}$ dia. $0.8 \mu \mathrm{m}$ Nuclepore ${ }^{\circledR}$ filter. Filters were preserved with $0.4 \%$ PFA, mounted onto glass slides and frozen at $-4{ }^{\circ} \mathrm{C}$ until counted. Synechococcus spp. were visualized by epifluorescence microscopy at $1000 \times$, under oil immersion where phycoerythrin and Chl $a$ are excited at green $(510-560 \mathrm{~nm})$ and blue $(450-490 \mathrm{~nm})$ wavelengths to observe their red fluorescence (Carpenter et al., 1999). Cryptophytes were identified in Lugol's iodine preserved samples which were stored in the dark until analysis by epifluorescence microscopy using their yellow-orange fluorescence signatures (Booth, 1993; MacIssac and Stockner, 1993).

Total phytoplankton biomass was measured in triplicate by filtering samples from discrete depths onto $25 \mathrm{~mm}$ Whatman ${ }^{\circledR} \mathrm{GF} / \mathrm{F}$ filters for estimation of $\mathrm{Chl}$ a concentrations $\left(\mathrm{mg} \mathrm{m}^{-3}\right.$ ) by fluorometry in a Turner Designs ${ }^{\circledR}$ TD700 fluorometer according to the procedure detailed in Knap et al. (1994).

Samples for the ALF were collected in $500 \mathrm{ml}$ amber glass bottles and stored in the dark under cold conditions for about 30 min to minimize the impacts of non-photochemical quenching before analysis. High-resolution spectral measurements of blue $(405 \mathrm{~nm})$ and green $(532 \mathrm{~nm})$ laser-stimulated emission were used to obtain fluorescence intensities attributable to chlorophyll $a$ (Chl $a$ ), phycoerythrin (PE), and CDOM (Chekalyuk and Hafez, 2008; Chekalyuk et al., 2012). All emission spectra were analyzed using spectral deconvolution technique to resolve the overlapped fluorescence bands of Chl $a$, CDOM, three taxa-specific spectral types of PE, and water Raman scattering (Chekalyuk and Hafez, 2008). The fluorescence intensities normalized to the water Raman were expressed as relative fluorescence units (RFU). The Raman-normalized $\mathrm{Chl} a(679 \mathrm{~nm})$ and CDOM $(508 \mathrm{~nm})$ fluorescence signals stimulated by the blue laser allow for measurements of Chl $a$ and CDOM, respectively, while the Raman-normalized PE fluorescence signatures stimulated with the green laser allow for detection and quantitative assessment of three PE-containing groups of phytoplankton. These include the: (1) PE-1 peak at $565 \mathrm{~nm}$ from blue water oligotrophic cya- nobacteria with high phycourobilin/phycoerythrobilin (PUB/PEB) ratios, (2) PE-2 peak at $578 \mathrm{~nm}$ from green water cyanobacteria with low-PUB/PEB ratios that usually thrive in coastal mesohaline waters, and (3) PE-3 peak at $590 \mathrm{~nm}$ attributable to eukaryotic photoautotrophic cryptophytes that are rich in phycobiliproteins and often abundant in coastal, and estuarine environments and in enclosed bays (Chekalyuk and Hafez, 2008; Chekalyuk et al., 2012).

Between stations, the ALF was connected to the ship's uncontaminated seawater flow-through system, together with other instruments allowing for continuous measurements of salinity and temperature, fluorometric $\mathrm{Chl} a$ and $\mathrm{pCO}_{2}$, in water from approximately $5 \mathrm{~m}$ below the surface along the cruise track shown in Fig. 1. With the exception of a few breaks for reconditioning, the ALF was operated throughout the cruise, providing near-real time distribution patterns of CDOM, Chl $a$ fluorescence, and the three different phycobilipigment phytoplankton types over a distance of $700 \mathrm{~km}$ inside and outside the plume. Starting from Station 9 onwards, samples were collected for inorganic nutrients and phytoplankton counts at hourly intervals along the cruise track. Phytoplankton samples were collected by gently filtering 4 to 61 of seawater from the flow-through system through a $20 \mu \mathrm{m}$ pore size Nitex mesh. The samples were gently backwashed off the net with about $50 \mathrm{ml}$ of filtered seawater and then fixed with Lugol's iodine for microscopic analysis. At every underway station sampled, seawater samples were also filtered through a $0.8 \mu \mathrm{m}$ Nuclepore ${ }^{\circledR}$ filter for enumeration of cells of Synechococcus spp. Thus, while our phytoplankton counts for the underway samples account for Synechococcus spp. they do not account for $<20 \mu \mathrm{m}$ phytoplankton other than Synechococcus spp., that would have passed through the $20 \mu \mathrm{m}$ pore size Nitex mesh.

\subsection{Statistical tests and data analysis}

The efficacy of the ALF for assessing phytoplankton Chl $a$ and for discriminating different phytoplankton groups was evaluated using simple correlation statistics between (1) ALF derived Chl $a$ and Chl $a$ measured fluorometrically in 90\% acetone extracted samples and (2) ALF derived phycobilipigments and microscopic counts.

Bray-Curtis cluster analysis was performed on 4th root transformed ALF data (Bray and Curtis, 1957; Clarke and Warwick, 2001) to assess similarities among the 27 stations samples and to evaluate whether clustering of the stations into groups, and separations among groups of stations were meaningful from an ecological context. Principal Component Analysis (PCA) (Chatfield and Collins, 1980; Clarke and Warwick, 2001) was also undertaken on $\log (x+1)$ transformed environmental and biological data to examine the importance of the Amazon River as a driver of changes in water column hydrography, chemistry and to assess what were the major environmental controls of phytoplankton community structure in the WTNA.

\section{Results}

4.1. Surface plume hydrography, nutrient chemistry and ALF-derived fluorescence patterns

During the summer of 2010, signatures of the Amazon River plume with salinities $<35$ could be traced as far north as $18^{\circ} \mathrm{N}$. The extent of the plume is also evident from the elevated Chl $a$ concentrations in the MODIS-Aqua imagery on which the cruise track and station locations are superimposed (Fig. 1). Sea surface salinity (SSS) measurements from the ship's underway system, ranged from 16.47 in the southern part of the plume to about 37.5 in 

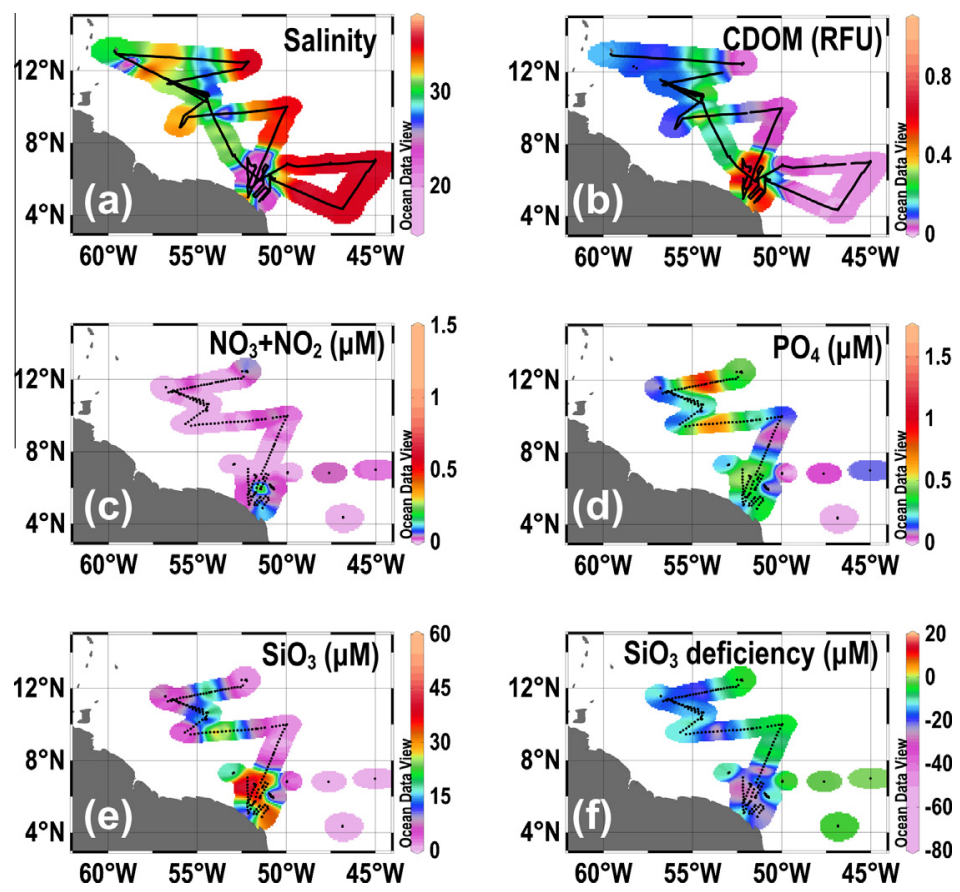

Fig. 2. Surface distribution of (a) salinity, (b) CDOM (RFU), (c) $\mathrm{NO}_{3}+\mathrm{NO}_{2}(\mu \mathrm{M})$, (d) $\mathrm{PO}_{4}(\mu \mathrm{M})$, (e) $\mathrm{SiO}_{3}(\mu \mathrm{M})$, and (f) $\mathrm{SiO} 3$ ( $\mu \mathrm{M}$ ), deficiency.

the north (Fig. 2a). Salinity gradients delimited the plume waters to a very narrow coastal band to the south, which dispersed and broadened off the continental shelf as the plume flowed northwards, consistent with satellite Chl $a$ distribution seen in Fig. 1. Offshore and outside of the influence of the plume, salinities reached a high of 37.5. Within the core of the plume, there were three conspicuous low surface salinity patches where salinity was much lower than at any other location within the plume (Fig. 2a). The southern-most patch located between $4^{\circ}$ and $8^{\circ} \mathrm{N}$, 57.5 and $59^{\circ} \mathrm{W}$ was the freshest and the largest of the three patches detected in the plume. Immediately outside of this patch, the salinity gradient was sharp, but became gradual along the long-shore axis of the plume thereafter (Fig. 2a). Water temperatures (data not shown) were higher $\left(\sim 30.4^{\circ} \mathrm{C}\right)$ within the core of the plume in the south, than in the surrounding WTNA $\left(\sim 28.5^{\circ} \mathrm{C}\right)$ outside the plume.

Plume waters, particularly in the core of the plume, were easily distinguishable by the ALF's high-resolution underway CDOM fluorescence measurements (Fig. 2b). Bulk of the plume waters was confined west of $50^{\circ}$ Wand as expected, $\mathrm{CDOM}$ concentrations were highest upstream, decreasing northwards along the alongshore axis of the plume. Although smaller in size, another patch of high $\mathrm{CDOM}$ fluorescence located in the north around $10^{\circ} \mathrm{N}$ and $54^{\circ} \mathrm{W}$ was coincident with the large patch of low salinity water (Fig. 2a and $\mathrm{b})$.

The influence of the Amazon River plume waters on nutrient $\left(\mathrm{NO}_{3}+\mathrm{NO}_{2}, \mathrm{PO}_{4}\right.$ and $\left.\mathrm{SiO}_{3}\right)$ concentrations in the WTNA is clearly discernible in surface plots (Fig. 2c-e), constructed using a combination of nutrient measurements from near-surface CTD samples and hourly samples collected from the ship's uncontaminated seawater flow-through system. Concentrations of $\mathrm{SiO}_{3}$ and $\mathrm{PO}_{4}$ were higher within the plume than in the surrounding oceanic waters, in particular, in the high-CDOM, low salinity waters to the south, decreasing as the plume dispersed northwards (Fig. 2e). The distribution of $\mathrm{PO}_{4}$ concentrations on the other hand, although higher in the plume was very patchy (Fig. 2d). With the exception of two small localized patches around $51.5^{\circ} \mathrm{W}$ and $5.5^{\circ} \mathrm{N}$ of $\sim 1.0 \mu \mathrm{M}$, inor- ganic $\mathrm{NO}_{3}+\mathrm{NO}_{2}$ concentrations were extremely low throughout the plume (Fig. 2c).

The spatial patterns of near sea surface $\mathrm{Chl} a$ fluorescence from the ALF underway and discrete samples (Fig. 3a) showed a small patch of high Chl $a$ onshore in the south, coincident with the area of low salinity, high CDOM and high $\mathrm{NO}_{3}+\mathrm{NO}_{2}$. Within this patch, ALF Chl $a$ fluorescence values were in excess of 20 RFU (Relative Fluorescence Units) and much higher than at any other location within the plume. Another patch of moderately high fluorescence $(\sim 5 \mathrm{RFU})$ was seen at $13^{\circ} \mathrm{N}, 59^{\circ} \mathrm{W}$. ALF derived variable fluorescence $\left(F_{v} / F_{m}\right)$ measurements showed that over large part of the plume including in the $\mathrm{Chl} a$-rich patches, phytoplankton populations were physiologically stressed.

Of the three phycobilipigments that the ALF discriminates (Fig. 3b-d), the spatial pattern of PE-3 fluorescence (Fig. 3d) typically associated with cryptophytes and green water Synechococcus spp., most closely resembled that of near surface Chl $a$. The spatial patterns of PE- 1 and PE-2 fluorescence were similar to each other, but the intensities of the latter were much higher than the former (Fig. 3c and d, note different scales). With the exception of a smaller patch towards the south, both PE-1 and PE-2 containing organisms dominated waters where salinities were in excess of 29 in contrast to the preference of PE-3 containing organisms for low salinity waters.

\subsection{Plume column hydrography, nutrient chemistry and fluorescence patterns}

Depth profiles for all hydrographic and chemical parameters (Fig. 4a-g) have been drawn along a transect that best depicts variability along north-south axis of the plume (Fig. 4h). At the resolution of the standard CTD-rosette sampling, density profiles along the long-shore axis of the plume depict a $\sim 5 \mathrm{~m}$ thick low salinity (Fig. 4a) surface lens extending from $5^{\circ} \mathrm{N}$ to $7^{\circ} 30^{\prime} \mathrm{N}$, and another slightly deeper $(\sim 18 \mathrm{~m})$ layer between $10^{\circ}$ and $11^{\circ} 30^{\prime} \mathrm{N}$, as the plume diffused and deepened towards the north. Outside of the 

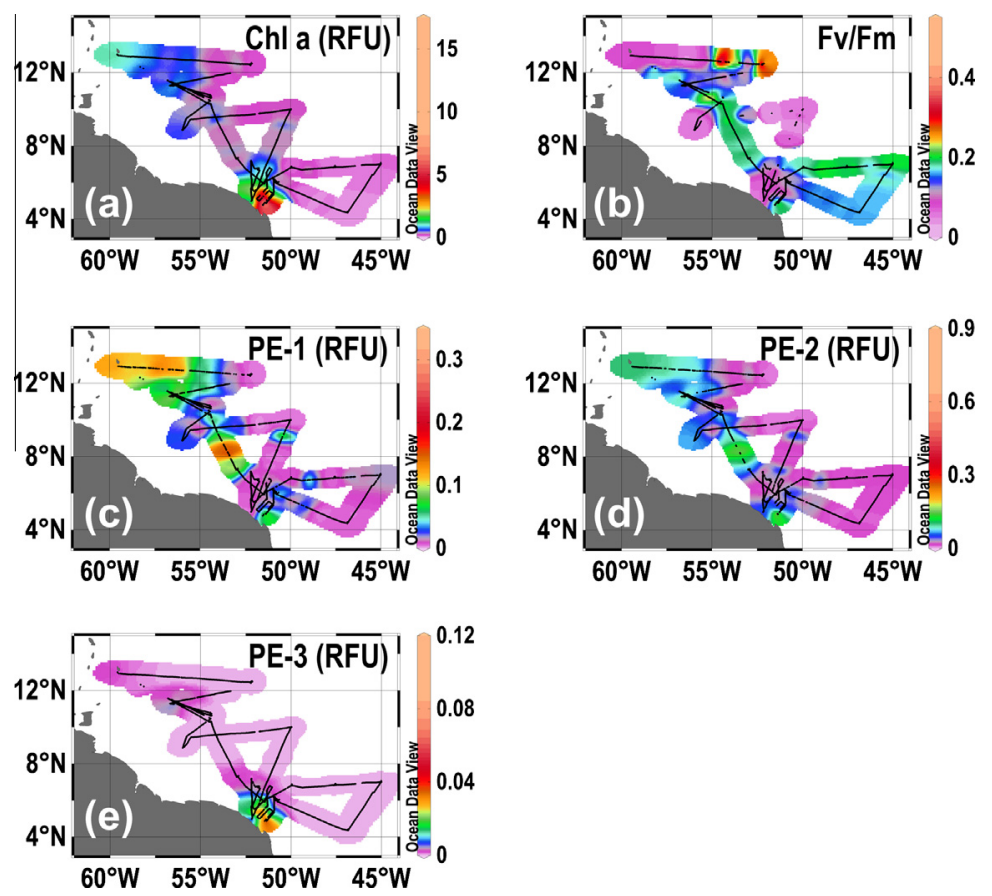

Fig. 3. Surface distribution of fluorescence (RFU) attributable to (a) Chl $a$, (b) $F_{v} / F_{m}$, (c) PE-1, (d) PE-2 and (e) PE-3.
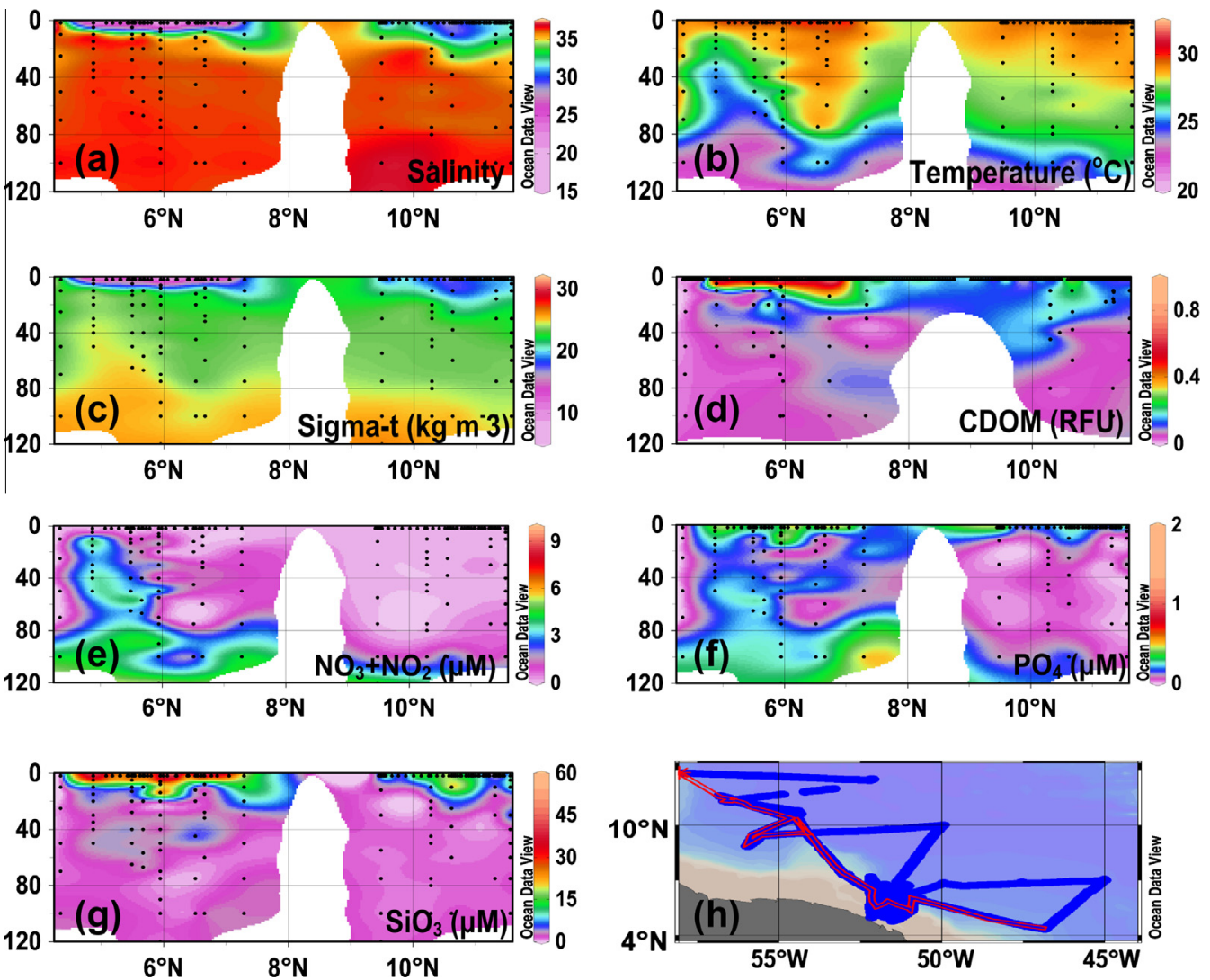

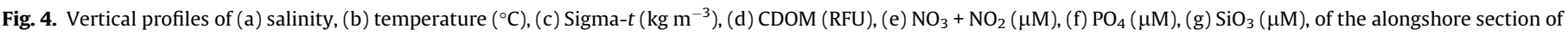
the Amazon River plume shown as a red line in $(\mathrm{h})$

plume, the waters were less stratified and mixed layer depths were in excess of $65 \mathrm{~m}$.

Temperature profiles across the north-south section showed a shoaling of isotherms from $120 \mathrm{~m}$ to about $20 \mathrm{~m}$ in the area between $5^{\circ}$ and $6^{\circ} \mathrm{N}$ (Fig. $4 \mathrm{~b}$ ). Within the plume waters, a combination of low salinity and higher temperatures (Fig. 4b) restricted mixed layer depths (Fig. 4c) to $\sim 5 \mathrm{~m}$ onshore and $\sim 18 \mathrm{~m}$ in the mesohaline waters offshore. Although the thickness of the surface 

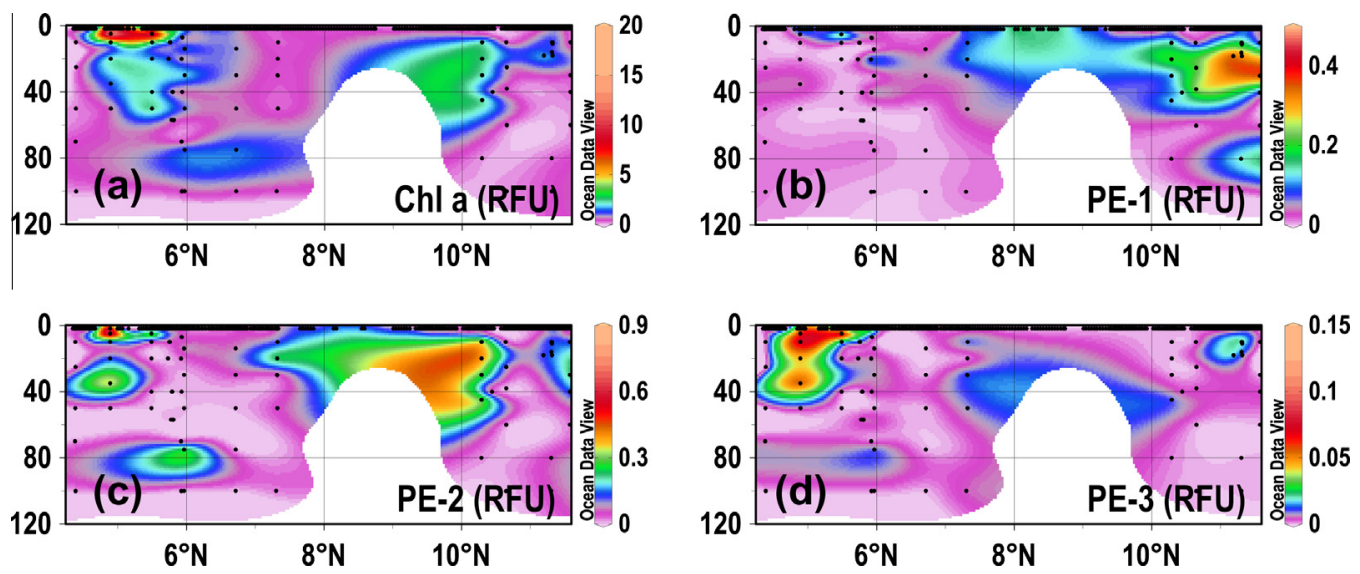

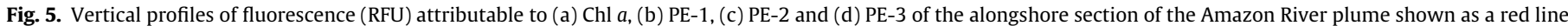
in Fig. $4 \mathrm{~h}$

plume waters was largely determined by the vertical salinity gradient, seawater temperature appeared to have a larger influence on the density of waters below the plume, as seen from the structure of the isotherms coincident with the density isopycnals (Fig. 4a-c). A cross-shore CTD section at this location (data not shown) indicated that the upward movement of water was due to the onshore advection of $120 \mathrm{~m}$ deep subsurface offshore waters onto the Amazon shelf.

Euphotic depths calculated from the scalar PAR measurements, ranged from 6 to $14 \mathrm{~m}$ in the low salinity, high CDOM, particle rich
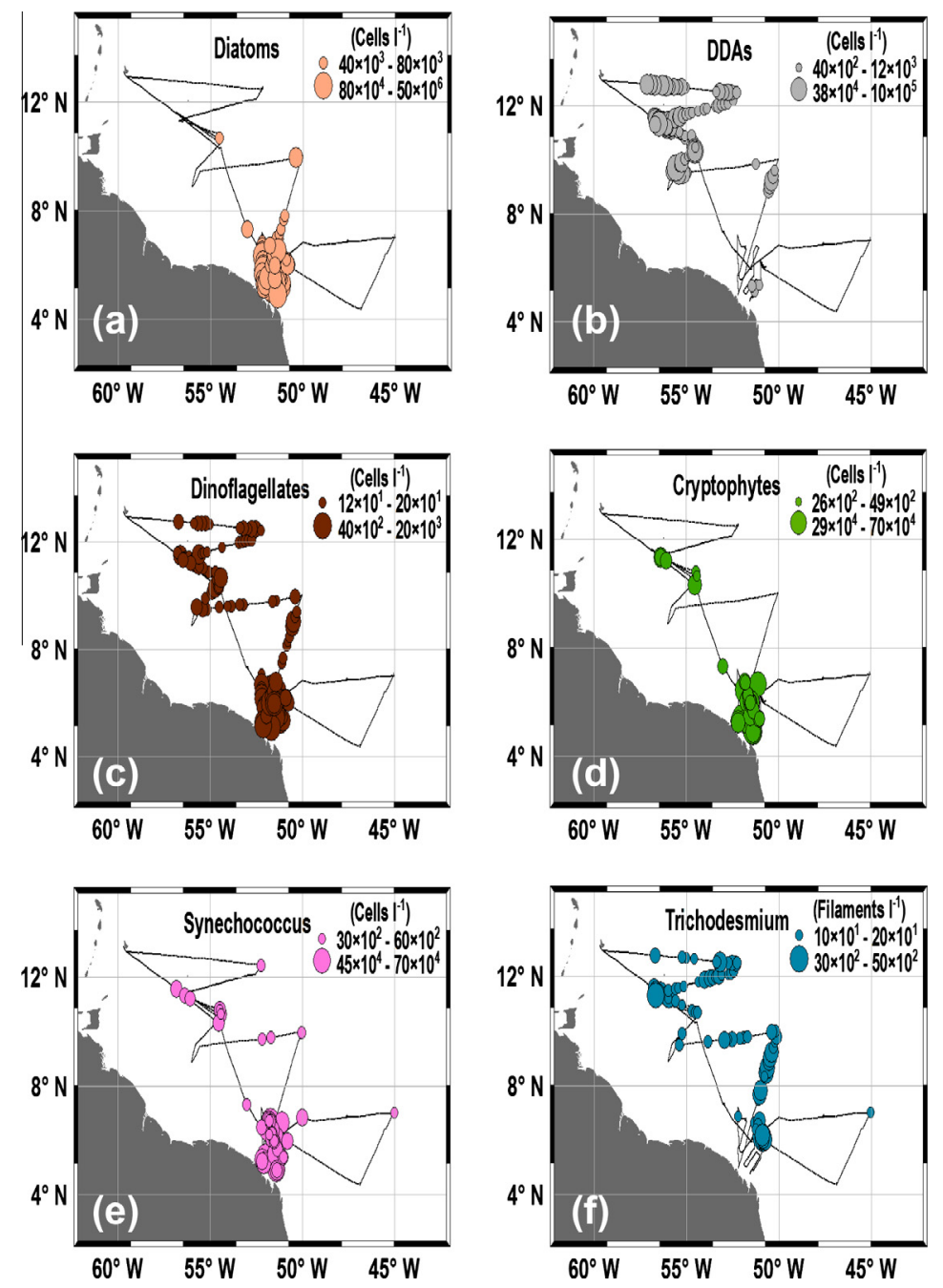

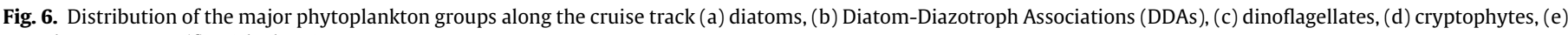
Synechococcus spp., (f) Trichodesmium spp. 
waters, $16-31 \mathrm{~m}$ in the mesohaline waters and $>70 \mathrm{~m}$ in the offshore oceanic waters.

CDOM concentrations along the $\mathrm{N}-\mathrm{S}$ section followed the distribution patterns of seawater salinity and density and were highest at the surface in the low salinity, low density southern patch between $5^{\circ} \mathrm{N}$ and $7^{\circ} 30^{\prime} \mathrm{N}$, decreasing northwards (Fig. 4d). The other slightly thicker $(\sim 18 \mathrm{~m})$ CDOM-rich water parcel was also coincident with the low salinity, low density water patch between $10^{\circ}$ and $11^{\circ} 30^{\prime} \mathrm{N}$.

Concentrations of $\mathrm{NO}_{3}+\mathrm{NO}_{2}$ were low throughout the plume both at the surface and in the water column except at $5^{\circ} \mathrm{N}$, where an upward influx of $\mathrm{NO}_{3}+\mathrm{NO}_{2}$ and $\mathrm{PO}_{4}$ coincident with the shoaling of isotherms, was observed (Fig. 4e). $\mathrm{SiO}_{3}$ concentrations were highest $(\sim 56 \mu \mathrm{M})$ in the low salinity, high-CDOM surface plume waters (Fig. 4f). In contrast to $\mathrm{NO}_{3}+\mathrm{NO}_{2}$ and $\mathrm{PO}_{4}, \mathrm{SiO}_{3}$ concentrations associated with the upward influx of appeared to be miniscule as compared to ambient $\mathrm{SiO}_{3}$ concentrations with the plume waters. Concentrations of $\mathrm{PO}_{4}$ on the other hand, were about $\sim 0.5 \mu \mathrm{M}$ upstream of the plume, but were higher $(\sim 0.9 \mu \mathrm{M})$ to the north at salinities $>23$. While the influx of $\mathrm{NO}_{3}+\mathrm{NO}_{2}$ and $\mathrm{PO}_{4}$ from the deeper depths into low salinity $(<18)$ waters in the south appeared to be quite substantial, it does not appear that the enhanced $\mathrm{PO}_{4}$ concentrations in the mesohaline and higher salinity waters to the north were associated with subsurface waters intrusions.

ALF profiles of Chl $a$ fluorescence from CTD bottle samples across the along-shore section showed a very high intensity ( $>20 \mathrm{RFU})$ core confined to the upper $(10 \mathrm{~m})$ low salinity, high CDOM waters of the plume in the south (Fig. 5a). The second patch of high Chl $a$ fluorescence intensities ( $>10 \mathrm{RFU}$ ) observed along this section was located in the subsurface layers $(5-60 \mathrm{~m})$ of the water column between $8^{\circ} 30^{\prime}$ and $10^{\circ} 30^{\prime} \mathrm{N}$. This patch of high Chl $a$ fluorescence was also the site where fluorescence signatures of the phycobilipigments, most notably PE-2 were most intense (Fig. 5c), indicating a large population of green water cyanobacteria at depth at this location. PE-2 fluorescence could be detected at the surface and at depth in the low salinity southern stations. The deeper patches at $35 \mathrm{~m}$ and $80 \mathrm{~m}$ were well below the euphotic zone but within mesohaline ( 33 ), low CDOM waters (Fig. $5 \mathrm{c}$ ). The most intense PE-3 fluorescence signatures observed in the south were co-located with the high Chl $a$ fluorescence patches, suggesting that a large proportion of the Chl $a$ was from eukaryotes and photoautotrophs (Fig. 5a and d). Elsewhere along this section, high PE-3 fluorescence signatures were observed in the low salinity patches to the north where they were also co-located with elevated Chl $a$ fluorescence intensities. In contrast to PE-2 and PE-3 fluorescence distribution patterns, PE-1 intensities were highest in the high salinity, low CDOM, low nutrient waters to the north (Fig. 5b) indicating the presence of blue water cyanobacterial populations.

\subsection{Relationship between ALF fluorescence patterns and phytoplankton counts}

The $15 \mathrm{~m}$ thick patch of elevated (>20 RFU) Chl $a$ intensities (Fig. 5a) in the south presumably fuelled by the cross-shore and upward influx of inorganic $\mathrm{NO}_{3}+\mathrm{NO}_{2}$ rich waters into the plume (Fig. 4e), was made up of a dense mixed population of diatoms comprising primarily of Skeletonema marinoi (sensu lato, costatum), Pseudo-nitzchia spp., Thalasiossira alienii, and Chaetoceros spp. (Fig. 6a). Farther north along this section at about $10^{\circ} \mathrm{N}$, where $\mathrm{SiO}_{3}$ and $\mathrm{PO}_{4}$ concentrations were high, but $\mathrm{NO}_{3}+\mathrm{NO}_{2}$ concentrations below detection limits, the elevated fluorescence intensities of Chl $a$ ( $<10 \mathrm{RFU})$ at the subsurface were from a large population of the DDAs (Fig. 6b), comprising mainly of Hemiaulus hauckii and some Rhizosolenia clevei. The presence of $R$. intracellularis as endos- ymbionts and in free form in this region was also reflected in the elevated concentrations of $\mathrm{PE}-2$ phycobilipigments. The distribution of dinoflagellates was more widespread, but they were present in far smaller numbers as compared to the other phytoplankton groups recorded in the plume (Fig. $6 \mathrm{c}$ ).

The elevated patch of high PE-3 fluorescence, coinciding with the high Chl $a$ fluorescence, diatom-rich patch to the south also contained large numbers of Synechococcus spp. and Cryptophytes (Fig. 6d and e). The presence of Synechococcus spp. and Cryptophytes was also evident from the elevated signatures of PE-2 and PE-3 respectively measured by the ALF. As pointed earlier, the increased PE-1 fluorescence at the northern-most point of the section was associated with elevated numbers of Trichodesmium spp. colonies and individual trichomes and cells of oceanic Synechococcus spp. (Fig. 6f)

Despite large variations in phytoplankton biomass across the plume, and the range of species encountered along the cruise track, the relationship between ALF Chl $a$ fluorescence intensities (RFU) and fluorometrically-derived $\mathrm{Chl} a$ concentrations $\left(\mathrm{mg} \mathrm{m}^{-3}\right)$ was significant $\left(R^{2}=0.82, p<0.001\right)$ for the entire range of Chl $a$ values. At lower concentrations $\left(<5 \mathrm{mg} \mathrm{m}^{-3} \mathrm{Chl} a\right.$ ), this relationship was much weaker, but statistically significant $\left(R^{2}=0.49, p<0.001\right.$, see inset to Fig. 7a).

Relationships between ALF-derived phycobilipigments from discrete samples and dominant phytoplankton groups identified microscopically are shown in Fig. 7b-d. On the basis of the correlation coefficients $\left(R^{2}\right)$ values, about $51 \%$ of the variability in the PE-1 fluorescence signatures across the entire cruise track could be accounted by Trichodesmium spp. The other dominant cyanophyte, Synechococcus spp. could have accounted the remaining fluorescence. DDAs accounted for about $59 \%$ of the variability in PE-2 fluorescence, particularly when RFU values were in excess of 0.05 (Fig. 7c). Cryptophytes clearly accounted for the bulk $(<90 \%)$ of the fluorescence intensities associated with PE-3 type phycobilipigments (Fig. 7d).

\subsection{Surface plume water nutrient-salinity relationships and nutrient drawdown}

Nutrient-salinity relationships for the three major nutrients within the plume revealed conspicuous deviations from the conservative mixing line obtained using seawater (salinity, 36) end member $\mathrm{NO}_{3}, \mathrm{PO}_{4}$, and $\mathrm{SiO}_{3}$ concentrations of 0,0 and $1.6 \mu \mathrm{M}$ respectively and Amazon River freshwater end member concentrations of $11.5,0.5$ and $155 \mu \mathrm{M}$ respectively. Concentrations of nutrients at the Amazon River mouth and further upstream were obtained as part of the River-Ocean Continuum of the Amazon (ROCA) program river cruises during May 2010 (Yager et al., in preparation). With a few exceptions, concentrations of $\mathrm{NO}_{3}+\mathrm{NO}_{2}$ were below detection limits over most of the study area, and when present, were much lower than expected based on the conservative mixing model. $\mathrm{SiO}_{3}$ on the other hand, showed a more conservative behavior, but $\mathrm{SiO}_{3}$ loss attributable to biological drawdown could be observed along the entire salinity gradient particularly between 17 and 33. The plot of $\mathrm{SiO}_{3}$ deficiency of surface plume waters (Fig. 3f) obtained using Amazon River and open ocean $\mathrm{SiO}_{3}$ end member concentrations measured by ROCA, showed two regions where the drawdown of $\mathrm{SiO}_{3}$ was substantial, the first was in the near shore low salinity, high CDOM southern water parcel dominated by diatoms, cryptophytes and Synechococcus spp., and the second was in the mesohaline waters, north of $8^{\circ} 30^{\prime} \mathrm{N}$ and west of $52^{\circ} 5^{\prime} \mathrm{W}$ where the DDAs H. hauckii and $R$. clevei were the major components of the phytoplankton community (Fig. 6a-f).

Inorganic $\mathrm{PO}_{4}$ concentrations did not display the clear conservative mixing behavior observed for $\mathrm{SiO}_{3}$, and at several locations, 

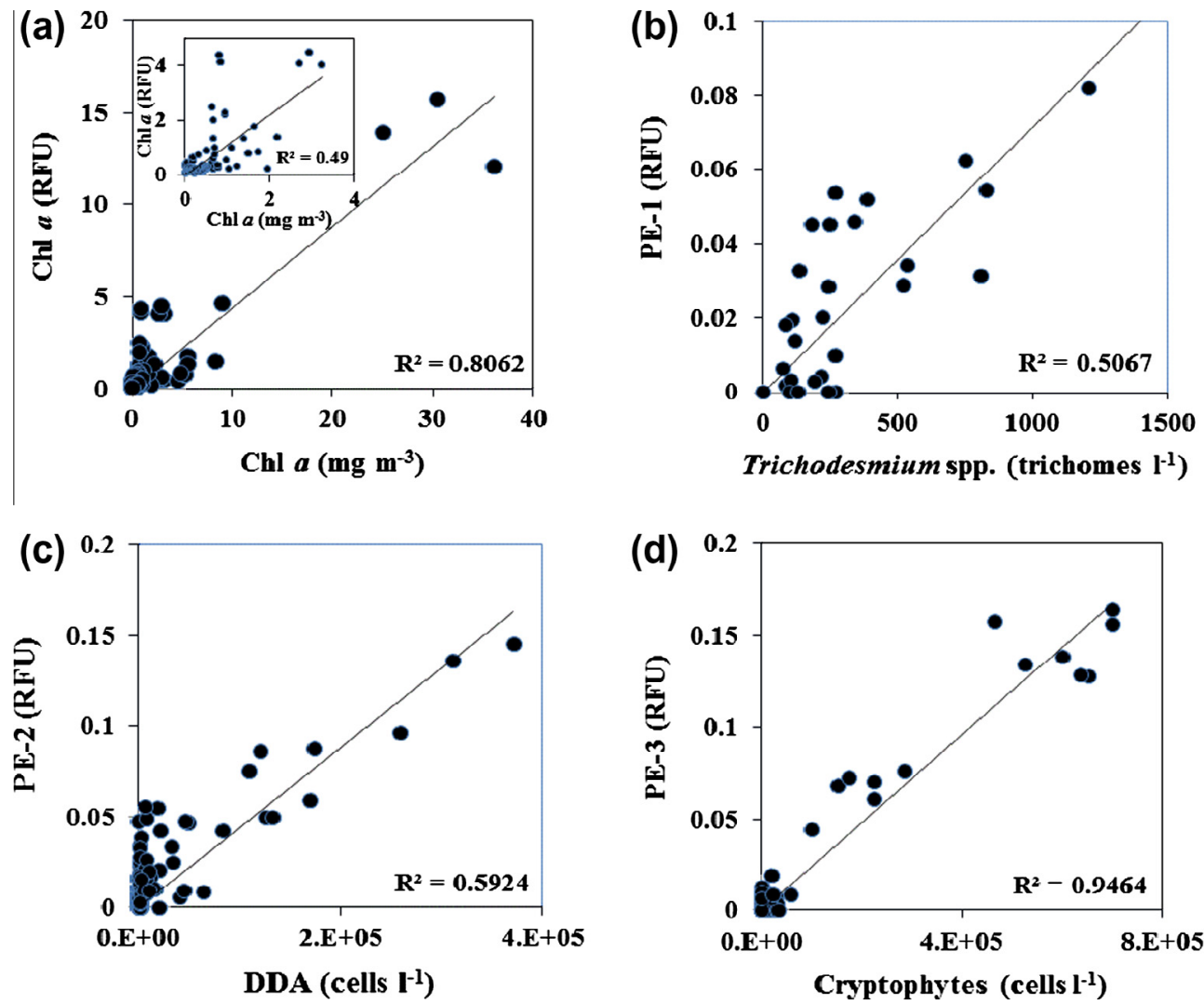

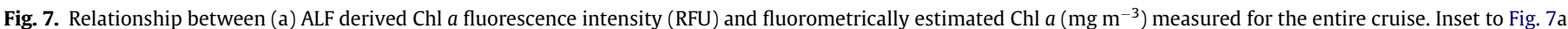

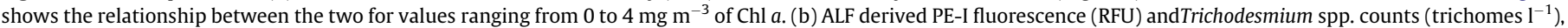

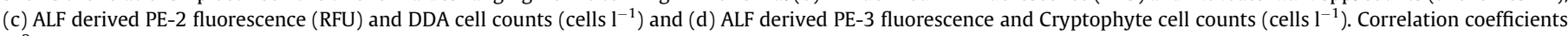
$\left(R^{2}\right)$ are displayed in each panel.

$\mathrm{PO}_{4}$ concentrations were above the mixing line, suggesting possible $\mathrm{PO}_{4}$ desorption and release from suspended particles in the plume waters as was reported earlier for these waters (DeMaster et al., 1986; Richey et al., 1989).

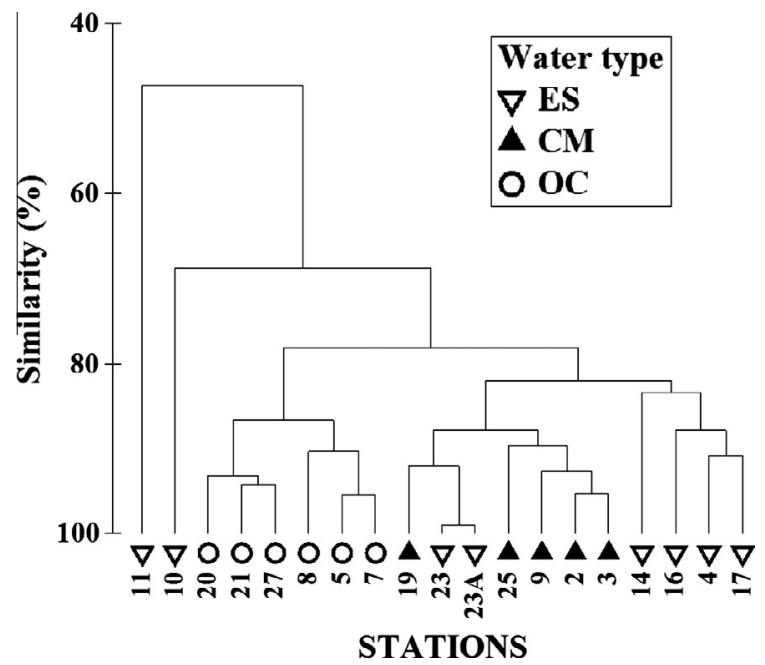

Fig. 8. Dendrogram for sampling stations based on the ALF fluorescence data from individual station, using Bray-Curtis similarity index and group average linkage. Symbols corresponding to the sampling stations are salinity-based on the classification of the stations into Estuarine (ES), coastal mesopelagic (CM) and Oceanic (OC).

\subsection{Statistical analysis}

A Bray-Curtis cluster analysis performed using ALF data (Bray and Curtis, 1957; Clarke and Warwick, 2001), (1) to evaluate similarities between the 27 stations occupied during the cruise and (2) to assess whether any grouping of stations was meaningful from an ecological perspective. The analysis separated the stations into three broad groups: (1) an "oceanic type" (OC) consisting of two sub-clades of high-salinity ( $>35$ ) stations, (2) an "estuarine type" (ES) comprising of low salinity (<28) stations and (3) a group made up of two sub-clades of "mesohaline type" (CM) (30-35) stations as seen in the dendrogram shown in Fig. 8. A Non-Metric Dimensional Scaling analysis performed on the data revealed strong similarities $(\sim 82 \%)$ between the OS stations. Similarly the $\mathrm{CM}$ stations were also tightly clustered. However a weaker degree of similarity was observed within the ES stations, perhaps a reflection of the large variability in Chl $a$ and phycobilipigment concentrations in these estuarine waters with widely varying salinities (Fig. 9).

\section{Discussion}

Our results suggest that freshwater discharge from the Amazon River has a substantial influence on phytoplankton assemblages and nutrient cycling in the WTNA Ocean through its influence on: (1) nutrients for phytoplankton growth (DeMaster and Pope, 1996; DeMaster et al., 1996; Santos et al., 2008; Smith and Russell,1995) and (ii) the hydrographic and light environment of the WTNA (Curtin, 1986; Curtin and Legeckis, 1986; DeMaster et al., 


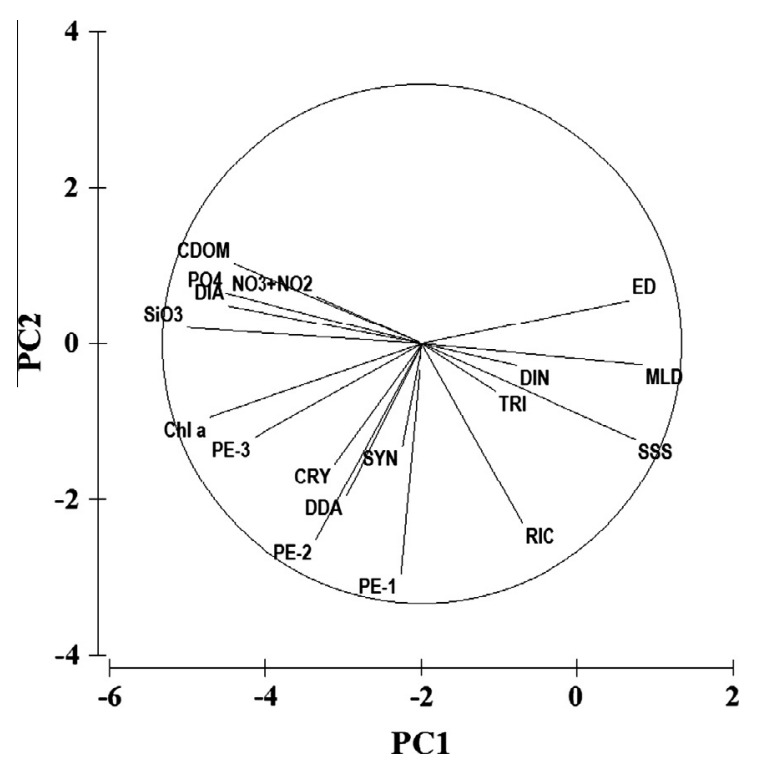

Fig. 9. Principal Component Analysis loading scores for the two principal component (PC) axes PCI ( $x$-axis) and PC2 ( $y$-axis). Abbreviations used CDOM (chromophoric dissolved organic matter), SSS (plume water salinity), MLD (mixed layer depth), ED (euphotic depth), TRI (Trichodesmium spp.), RIC (Richelia intracellularis), CRY (Cryptophytes), DDA (Diatom-Diazotroph Association), DIN (Dinoflagellates).

1986; Gibbs, 1976b; Lentz, 1995a). Although riverine nutrient concentrations $\left(\mathrm{SiO}_{3}-155 \mu \mathrm{M}, \mathrm{NO}_{3}+\mathrm{NO}_{2}-11.5 \mu \mathrm{M}\right.$ and $\mathrm{PO}_{4}-$ $0.5 \mu \mathrm{M})$ measured during the period of peak river discharge in May of 2010 are considerably lower than other large rivers such as the Yangtze, Mississippi and Yellow Rivers (Turner, 2003), the large volume of freshwater that is discharged by the Amazon River offsets these differences (McKee et al., 1986). $\mathrm{NO}_{3}+\mathrm{NO}_{2}$ concentrations in particular were low throughout the surface plume waters except at the low salinity, high CDOM stations where the highest concentrations recorded were $\sim 1.46 \mu \mathrm{M}$. The corresponding salinity recorded at these stations was 18.1 which amounts to biological drawdown of $\mathrm{NO}_{3}+\mathrm{NO}_{2}$ approximating $73.7 \%$ after reductions attributable to dilution caused by mixing of riverine water with oceanic water are accounted for.

$\mathrm{NO}_{3}+\mathrm{NO}_{2}$ concentrations were even lower in the low salinity (16.6) southern shelf stations further upstream (Fig. 2c) suggesting that biological uptake was rapidly depleting nutrients that were being discharged by the river. This was also true for $\mathrm{SiO}_{3}$, whose concentrations at many locations along the cruise track, were below the conservative mixing line suggesting active biological drawdown (Fig. 2f). The region of greatest $\mathrm{SiO}_{3}$ deficiency in the upstream region of the plume was co-located with the high Chl $a$ patch which was dominated by the diatomsS. marinoi, Pseudo-nitzchia spp., T. alienii and Chaetoceros spp, as well as Synechococcus spp. and Cryptophytes, implying a significant role for these organisms for the drawdown of $\mathrm{SiO}_{3}$ (Fig. 6a, d and e). Assimilation of $\mathrm{SiO}_{3}$ and its accumulation by diatoms, particular for silica frustule formation are well known and the significance of this group of phytoplankton for $\mathrm{SiO}_{3}$ export upstream of the Amazon River plume was evident from large sinking aggregates of diatoms found in seawater samples from deeper depths. Besides diatoms there are certain phytoplankton groups of phytoplankton with no known requirement of $\mathrm{SiO}_{3}$, that have the capacity to accumulate $\mathrm{SiO}_{3}$ (Nelson et al., 1984; Schultze-Lam et al., 1992; Baines et al., 2012). In the most recent study (Baines et al., 2012), which involved experiments with laboratory cultures and natural samples, it was observed that Synechococcus sp. are capable of accumulating large amounts of $\mathrm{SiO}_{3}$. Results from the oligotrophic, silica-poor waters of the Easter Equatorial Pacific revealed that accumulation by Synechococcus spp. could account for between $40 \%$ and $200 \%$ of the amount attributable to diatoms (Baines et al., 2012). The exact mechanism for $\mathrm{SiO}_{3}$ accumulation in Synechococcus spp. is not known especially, because this organism lacks membrane bound vacuoles for $\mathrm{pH}$ manipulation necessary for the uptake of $\mathrm{SiO}_{3}$. In $\mathrm{SiO}_{3}$-rich waters such as the Amazon River plume, Synechococcus cells can act as nucleating sites for mineral formation (SchultzeLam et al., 1992). On account of their presence in large numbers in the upper reaches of the Amazon, we suggest that Synechococcus populations could be playing a far greater role in the cycling of $\mathrm{SiO}_{3}$ than previously recognized. At present there is no comparable data for cryptophytes and therefore any inference of their involvement in $\mathrm{SiO}_{3}$ cycling in the Amazon River plume could at best be speculative. Among the nutrients, $\mathrm{NO}_{3}+\mathrm{NO}_{2}$ concentrations were generally limiting in the surface plume waters, but the biomass rich patch (Chl $a$ fluorescence $\sim 20 \mathrm{RFU}$, Fig. 3a) appeared to be supported by the onshore advection of $\mathrm{NO}_{3}+\mathrm{NO}_{2}$-rich subsurface ( $120 \mathrm{~m}$, Figs. $2 \mathrm{c}$ and $4 \mathrm{e}$ ) and was further advantaged by the shallow mixed layer and large ambient concentrations of $\mathrm{SiO}_{3}$ and $\mathrm{PO}_{4}$. Entrainment of offshore subsurface North Brazilian Current waters onto the Amazon shelf observed by us has been reported previously (DeMaster and Pope, 1996; Gibbs, 1972; Nittrouer et al., 1991). It can be especially intense during the months of June-July, when outflow of freshwater from the Amazon River is at its peak, the trade winds are weak, and the northward movement of the Brazilian current along the coast of South America is very strong (25-30 Sv) (Curtin, 1986). While $\mathrm{NO}_{3}+\mathrm{NO}_{2}$ and to a certain extent $\mathrm{PO}_{4}$ enrichment of the plume waters attributable to on-shelf advection of offshore subsurface waters was substantial, $\mathrm{SiO}_{3}$ enrichment was small compared to its ambient concentrations in the surface plume waters, indicating that the subsurface waters are not an important source of $\mathrm{SiO}_{3}$ to the plume.

Hydrographic measurements suggest strong stratification of the upper water column due to the low density of the plume waters in the south (Fig. $4 \mathrm{a}-\mathrm{c}$ ). In waters that are very turbid and CDOM-rich, stratification is essential for retaining phytoplankton in the upper lighted layers, especially in the Amazon River plume where CDOM and suspended material concentrations were very high and the two acting in concert were responsible for the greatly reduced levels of light penetration in the shelf stations (Gomes et al., unpublished results). Strong stratification would have ensured that the resident phytoplankton were confined to the upper surface waters where sufficient light was available for photosynthesis, growth and accumulation to bloom proportions.

Within the DDA-dominated patch, salinity levels ranged from 28 to $33, \mathrm{SiO}_{3}$ from 16 to $35 \mu \mathrm{M}$ and $\mathrm{PO}_{4}$ from 0.5 to $0.9 \mu \mathrm{M}$, whereas $\mathrm{NO}_{3}+\mathrm{NO}_{2}$ concentrations were below detection limits. When $\mathrm{SiO}_{3}$ and $\mathrm{PO}_{4}$ are not limiting, DDAs are capable of photosynthesizing and growing actively in the absence of dissolved inorganic nitrogen, because their nitrogen requirements are met via the $\mathrm{N}_{2}$ fixing ability of their endosymbiont $R$. intracellularis (Foster et al., 2007, 2011). Using a combination of the uptake of stable isotope of $\mathrm{N}_{2}$ and high-resolution nanometer scale secondary ion mass spectrometry, Foster et al. (2011), estimated that Richelia spp. can fix between $81 \%$ and $744 \%$ more $\mathrm{N}_{2}$ than needed for their own growth, and that up to $97 \%$ of the fixed $\mathrm{N}_{2}$ could be transferred to their diatom partners. This unique endosymbiotic association allows DDAs to outcompete other organisms in the Amazon River plume and flourish when $\mathrm{SiO}_{3}$ and $\mathrm{PO}_{4}$ are available but dissolved inorganic nitrogenous nutrients are limiting (Shipe et al., 2006; Subramaniam et al., 2008).

With the exception of a few locations to the south where $\mathrm{PO}_{4}$ drawdown was evident, $\mathrm{PO}_{4}$ concentrations were invariably above the conservative mixing line in most of the surveyed areas, particularly where salinities exceeded 23 . Excess $\mathrm{PO}_{4}$ concentrations above the conservative mixing line were also recorded in plume 
waters away from the shelf. This abundant availability of $\mathrm{PO}_{4}$ would have ensured sustained growth of Synechococcus spp., DDAs andTrichodesmium spp. even under reduced $\mathrm{SiO}_{3}$ concentrations in the oligotrophic waters offshore.

The high-resolution underway ALF fluorescence measurements (Fig. 3a-e) when examined in the context of environmental variables were of immense utility in establishing the importance of $\mathrm{NO}_{3}+\mathrm{NO}_{2}$ as a modulator of structural changes in phytoplankton community within the Amazon River plume. Diatoms, cryptophytes and Synechococcus spp. consistently dominated in areas where $\mathrm{NO}_{3}+\mathrm{NO}_{2}$ were available even at low concentrations. The efficacy of the fluorescence signatures derived by the ALF as determinants of Chl $a$ and of phytoplankton groups is supported by the correlation analyses (Fig. 7a-d). The potential of the ALF to provide reliable estimates of Chl $a$ and the distribution patterns of the dominant groups of phycobiliprotein-containing phytoplankton, demonstrate its promise and potential for the structural characterization of phytoplankton communities, including high-resolution underway mapping (Chekalyuk and Hafez, 2008; Chekalyuk et al., 2012). The ease of its use and the spatial coverage it provides are especially beneficial when the area to be sampled is large and conventional methods pose the perennial problem of under sampling. The low $F_{v} / F_{m}$ values recorded by the ALF throughout provided us with indications of plume water populations that were consistently physiologically stressed, presumably due to $\mathrm{NO}_{3}+$ $\mathrm{NO}_{2}$ limitation. PE-1 fluorescence of blue-water types of cyanobacteria measured by the ALF could be attributed in large part to Trichodesmium spp. whereas DDAs were the major groups contributing to the PE-2 fluorescence and the cryptophytes to PE-3 fluorescence (Figs. 3a-e and 6a-f).

Although $\mathrm{NO}_{3}+\mathrm{NO}_{2}$ availability seems to be an important determinant of phytoplankton composition in the plume, cluster analysis of ALF fluorescence data suggests an important ecological role for salinity. As mentioned earlier, at locations heavily impacted by suspended particles and CDOM, the strong vertical stratification caused by of the low salinity of the plume waters, would have greatly aided in the retention of phytoplankton in the upper water layer, where sufficient light was available for photosynthesis and growth especially by diatoms, green water Synechococcus spp. and cryptophytes.

The ecological significance of salinity is evident from the clustering of stations in the dendrogram (Fig. 8), constructed with the help of Bray Curtis analysis of ALF pigment fluorescence data. which showed two tight clusters, one of high salinity OC stations and the other of CM stations. A third cluster made up largely of low salinity ES stations was physically separated from the other two clusters, but was more dispersed, because of the large differences in Chl $a$ within these stations. For instance Chl $a$ concentrations at stations 10 and 11, which were distal within the ES cluster were 36.1 and $25.1 \mathrm{mg} \mathrm{m}^{-3}$ respectively, much higher than the concentrations measured at any of the other stations within this group. The two other ES stations 23 and 23A which clustered with the CM stations had salinities of 29 and 26.6 respectively, far higher than any other ES stations. The disconnected nature of some of the stations within the ES cluster is not unexpected as salinities, nutrient concentrations and all other ecologically relevant variables such as CDOM, turbidity and euphotic depths varied widely among stations within this group.

The separation of the three groups based solely on salinity, however reinforces the view that salinity is an important determinant of phytoplankton community structure within the Amazon River plume. Although there are no known studies that have addressed the effects of salinity on the physiology of phytoplankton from the Amazon River plume, generally in estuarine ecosystems, salinity does have an important physiological control on phytoplankton (Brand, 1984). Estuarine diatoms and cryptophytes in particular have been shown to have increased rates of photosynthesis at reduced salinities (Brand, 1984; Qasim et al., 1972). Cryptophytes were found in large numbers in the southern low-salinity plume waters (Fig. 6d). These organisms have not been reported as a significant component of phytoplankton in past studies of the Amazon plume (Carpenter et al., 1999; Shipe et al., 2006; Subramaniam et al., 2008; Teixeira and Tundisi, 1967; Wood, 1966), possibly because of their relatively small size compared to diatoms which makes their microscopic identification difficult. The strong correlation between PE-3 fluorescence from ALF and cryptophyte counts from epifluorescence microscopy validates the reliability of the ALF to differentiate this group, as well as provide us with a convenient method to measure their concentrations over large areas. Vertical profiles of PE-3 fluorescence in the water column, indicated that cryptophytes were capable of growing under low light conditions, a physiological trait that afforded them the ability to thrive in the highly turbid, CDOM-rich, light-limited waters of the Amazon River plume. Although cryptophytes contain $\mathrm{Chl} a$, they are also rich in Chl c, carotenoids and PE-3 type of phycobilipigments which absorb a wide range of wavelengths, particularly yellowish green light which can penetrate deeper into water column, allowing them to thrive in high CDOM and high turbidity induced low light conditions (Haxo and Fork, 1959; Kirk, 1994). Cryptophytes are also capable of sustaining their growth via the uptake of organic compounds under light-limiting conditions (Gervais, 1997; Lewitus and Caron, 1991) explaining their presence below the euphotic zone at the southern stations. This mixotrophic behavior gives cryptophytes an advantage over other groups of phytoplankton under light limiting, high-CDOM conditions (Dokulil and Skolaut, 1986). The presence of cryptophytes in low-salinity, low-nutrient waters is not uncommon and these organisms are known to succeed diatoms when $\mathrm{SiO}_{3}$ limitation leads to the termination of a diatom bloom (Dokulil and Skolaut, 1986). At the southern end of the plume, $\mathrm{SiO}_{3}$ concentrations were particularly high; furthermore, there was an external source of $\mathrm{NO}_{3}+\mathrm{NO}_{2}$ that sustained the intense bloom of diatoms. Thus rather than confirm to a pattern of phytoplankton succession, our observations indicate that cryptophytes, diatoms and Synechococcus spp. co-exist in the low salinity, highCDOM and turbid waters of the Amazon River plume.

The elevated PE-2 fluorescence in the southern portion of the transect (Fig. 3c) was coincident with the presence of a greenwater Synechococcus spp. while the "oceanic" cluster $(>35 \% 0)$ was largely composed of blue-water cyanobacteria as indicated by their specific PE-1 fluorescence (Fig. 3b). Microscopy showed that the diazotrophic Trichodesmium and Synechococcus spp. were the major contributors to the PE-1-containing cyanobacterial populations in this area. Inorganic $\mathrm{PO}_{4}$, a key nutrient for diazotrophs such as Trichodesmium spp. and Synechococcus spp., as well as for DDAs such as $R$. intracellularis was not limiting at salinities above 28 , in which the "oceanic" and the "mesohaline" (H. hauckii and R. clevei) phytoplankton communities thrived. The lack of $\mathrm{NO}_{3}+\mathrm{NO}_{2}$ was not an issue for these two communities because their cellular nitrogen requirements can be met through atmospheric $\mathrm{N}_{2}$ fixation. The spatial separation of PE-2-rich DDAs stations from those dominated by PE-1-containingTrichodesmium spp. and oceanic Synechococcus was thus largely on the basis of salinity.

The significance of the Amazon River as a driver of changes in water column hydrography, chemistry of the WTNA and composition of phytoplankton communities across the plume is best illustrated by results ofthe Principal Component Analysis (PCA) (Chatfield and Collins, 1980) of the ALF, microscopic and environmental data. This analysis which incorporates all the ancillary environmental data collected during the cruise, yielded 5 axes that explained around $82 \%$ of the variability in this system (Table 1 ). Correlations between components for each PC axis are shown in Table 1, while Fig. 9 depicts the variability associated with first 
Table 1

Results of Principal Component Analysis performed using hydrological, chemical and biological data obtained from CTD stations occupied during the cruise. Significant $(p<0.01)$ correlations among components within each PC axis are shown in bold. Abbreviations used CDOM (chromophoric dissolved organic matter), SSS (plume water salinity), MLD (mixed layer depth), ED (euphotic depth), TRI (Trichodesmium spp.), RIC (Richelia intracellularis), CRY (cryptophytes), DDA (Diatom-Diazotroph Association), DIN (dinoflagellates).

\begin{tabular}{lrrrrr}
\hline & Axis-1 & Axis-2 & Axis-3 & Axis-4 & Axis-5 \\
\hline \% Variation explained & 36.10 & 17.60 & 11.50 & 9.10 & 7.50 \\
Chl $a$ & $-\mathbf{0 . 8 2}$ & -0.28 & -0.42 & -0.13 & -0.06 \\
CDOM & $-\mathbf{0 . 7 3}$ & 0.31 & 0.16 & 0.47 & 0.16 \\
$\mathrm{PE}-1$ & -0.08 & $-\mathbf{0 . 8 9}$ & 0.26 & 0.04 & 0.24 \\
$\mathrm{PE}-2$ & -0.41 & $-\mathbf{0 . 7 6}$ & -0.38 & -0.07 & 0.23 \\
$\mathrm{PE}-3$ & $-\mathbf{0 . 6 5}$ & -0.36 & -0.55 & -0.04 & 0.14 \\
$\mathrm{SSS}$ & $\mathbf{0 . 8 2}$ & -0.37 & -0.15 & 0.26 & -0.19 \\
$\mathrm{PO}_{4}$ & $\mathbf{- 0 . 7 6}$ & 0.19 & -0.08 & 0.50 & 0.02 \\
$\mathrm{SiO}_{3}$ & $-\mathbf{0 . 9 1}$ & 0.06 & 0.11 & 0.32 & 0.04 \\
$\mathrm{NO}_{3}+\mathrm{NO}_{2}$ & -0.40 & 0.18 & 0.02 & $-\mathbf{0 . 7 8}$ & -0.06 \\
$\mathrm{MLD}$ & $\mathbf{0 . 8 5}$ & -0.08 & -0.27 & 0.03 & -0.13 \\
$\mathrm{ED}$ & $\mathbf{0 . 8 0}$ & 0.17 & -0.12 & 0.35 & -0.06 \\
$\mathrm{TRI}$ & 0.28 & -0.18 & $-\mathbf{0 . 4 5}$ & -0.09 & $\mathbf{0 . 5 4}$ \\
$\mathrm{RIC}$ & 0.39 & $-\mathbf{0 . 6 9}$ & 0.21 & 0.27 & 0.15 \\
$\mathrm{SYN}$ & -0.08 & -0.39 & 0.26 & -0.17 & $-\mathbf{0 . 4 6}$ \\
$\mathrm{DDA}$ & -0.29 & $-\mathbf{0 . 5 8}$ & $\mathbf{0 . 7 1}$ & 0.11 & -0.09 \\
$\mathrm{DIA}$ & $-\mathbf{0 . 7 5}$ & 0.15 & 0.29 & -0.11 & 0.02 \\
$\mathrm{CRY}$ & -0.34 & -0.46 & -0.24 & -0.02 & $-\mathbf{0 . 6 5}$ \\
$\mathrm{DIN}$ & 0.37 & -0.08 & $\mathbf{0 . 5 1}$ & -0.35 & 0.41 \\
\hline
\end{tabular}

the two axes PC1 ( $x$ axis) and PC2 ( $y$ axis). The first axis (PC1) which includes sea surface salinity (SSS), mixed layer depths (MLD) and euphotic depths (ED), $\mathrm{SiO}_{3}, \mathrm{PO}_{4}$ and CDOM in the opposite direction, accounted for $36.1 \%$ of the variability and highlights the importance of salinity-driven changes in hydrography, nutrients and water column transparency on total phytoplankton biomass within the plume. Strong correlations between CDOM, SSS, MLD, ED and $\mathrm{SiO}_{3}$ and $\mathrm{PO}_{4}$ concentrations reinforce the view that the Amazon River plume has (1) an important influence on the hydrographic and underwater light environment of the plume and (2) is a large source of the nutrients, $\mathrm{SiO}_{3}$ and $\mathrm{PO}_{4}$ but, not of $\mathrm{NO}_{3}+\mathrm{NO}_{2}$. The first axis also emphasizes the contributions of diatoms and cryptophytes to the high biomass within the plume and their preference for low salinity, high $\mathrm{CDOM}, \mathrm{SiO}_{3}$ and $\mathrm{PO}_{4}$ rich waters.

Component loadings within the PC2 ( $y$ axis) accounted for $17.6 \%$ of the observed variability, illustrating the importance of "mesohaline" communities of DDAs and Richelia spp. to the overall variability in the system. DDAs appeared to be the dominant phytoplankton group within mesohaline waters and co-varied with $R$. intracellularis and PE-2-type phycobilipigments concentrations. The strong correlation observed for PE-1 and PE-2 type phycobilipigments within Axis 2, and the lack of a correlation between PE-1 and Trichodesmium spp., suggests the significance of other oceanic type cyanobacterial groups (e.g., Synechococcus spp.) in oceanic waters. The contribution of DDA and Richelia spp. to high PE-2 signatures is emphasized within this axis. Stations that had deeper mixed layers and were low in nutrients appear to favor Trichodesmium spp. and dinoflagellates (Fig. 9). On the other hand stations with a, PE-2 type organisms including DDA and Richelia spp. are distributed along the salinity, nutrient and mixed layer depth continuum in the plume. Axis 3, included contributions by Trichodesmium spp., and dinoflagellates accounted for $11.5 \%$ of the system variability. Combined loadings for, axes 4 and 5 accounted for $16.6 \%$ of the variability. $\mathrm{NO}_{3}+\mathrm{NO}_{2}$ accounted for a large fraction of the variability in Axis 4. Variability within Axis 5 was largely due to the variability in cell numbers of cryptophytes, Synechococcus spp. and Trichodesium spp. The negative and positive signs of correlations between these two groups of organisms, appears to be a reflection of their tolerance for the opposite ends of the salinity spectrum.

\section{Conclusions}

Our study shows that freshwater discharge from the Amazon River and its interaction with oceanic waters of the WTNA impacts phytoplankton biomass distribution and community structure far beyond the continental shelf. The mixing of riverine water rich in nutrients, suspended particles and CDOM with oceanic waters of the WTNA creates a range of habitats with varied salinities, nutrient concentrations and light conditions, in which certain communities of phytoplankton are able to thrive and outcompete others. The existence of these different niches within the Amazon River plume waters was clearly made evident by the high-resolution underway measurements of the ALF in conjunction with the microscopic analyses. The multivariate statistical analysis of ALF data allowed us to identify three distinct phytoplankton communities: (1) an "estuarine type" community dominated by diatoms, cryptophytes and green-water Synechococcus spp., (2) a "mesohaline type" dominated by DDAs, and (3) an "oceanic type" dominated by Trichodesmium spp. and blue water Synechococcus spp. Nutrient measurements indicated that the "estuarine type" population was capable of a substantial drawdown of $\mathrm{SiO}_{3}$ and other nutrients over and above the drawdown possible by DDAs. While earlier studies in the WTNA have attributed significant carbon drawdown to DDAs and Trichodesmium spp., our study shows that diatoms and possibly the phototrophic cyanobacteria Synechococcus spp and cryptophytes could play significant biogeochemical roles in the Amazon River plume. Finally this study demonstrates the utility of the ALF, especially in surveying phytoplankton groups across large oceanic areas, where conventional microscopic analyses are difficult, and time as well as labor-intensive.

\section{Acknowledgements}

This study has been funded by the US National Science Foundation Grant Number 1133277. The authors are grateful to the Captain and crew of $R / V$ Knorr and to Ajit Subramaniam, Lamont Doherty Earth Observatory for their support during the cruise and to Kali McKee for help with the data analysis. This is Lamont Doherty Earth Observatory contribution 7716.

\section{References}

Baines, S.B., Twining, B.S., Brzezinski, M.A., Krause, J.W., Vogt, S., Assael, D., McDaniel, H., 2012. Significant silicon accumulation by marine picocyanobacteria. Nature Geoscience 5, 886-891.

Berhane, I., Sternberg, R.W., Kineke, G.C., Milligan, T.G., Kranck, K., 1997. The variability of suspended aggregates on the Amazon Continental Shelf. Continental Shelf Research 17, 267-285.

Booth, B.C., 1993. Estimating Cell Concentration and Biomass of Autotrophic Plankton using Microscopy. Lewis Publishers, Boca Raton, Florida, USA.

Brand, L.E., 1984. The salinity tolerance of forty-six marine phytoplankton isolates. Estuarine, Coastal and Shelf Science 18, 543-556.

Bray, J.R., Curtis, J.T., 1957. An ordination of the upland forest communities of Southern Wisconsin. Ecological Monographs 27, 325-349.

Capone, D.G., Burns, J.A., Montoya, J.P., Subramaniam, A., Mahaffey, C., Gunderson, T., Michaels, A.F., Carpenter, E.J., 2005. Nitrogen fixation by Trichodesmium spp.: an important source of new nitrogen to the tropical and subtropical north Atlantic ocean. Global Biogeochemical Cycles 19, GB2024.

Carpenter, E.J., Montoya, J.P., Burns, J., Mulholland, M.R., Subramaniam, A., Capone, D.G., 1999. Extensive bloom of a $\mathrm{N}_{2}$-fixing diatom/cyanobacterial association in the tropical Atlantic Ocean. Marine Ecology Progress Series 185, 273-283.

Chatfield, C., Collins, A.J., 1980. Introduction to Multivariate Analysis. Chapman and Hall, London.

Chekalyuk, A., Hafez, M.A., 2008. Advanced laser fluorometry of natural aquatic environments. Limnology and Oceanography, Methods 6, 591.

Chekalyuk, A.M., Landry, M.R., Goericke, R., Taylor, A.G., Hafez, M.A., 2012. Laser fluorescence analysis of phytoplankton across a frontal zone in the California Current ecosystem. Journal of Plankton Research 34, 761-777. 
Chérubin, L.M., Richardson, P.L., 2007. Caribbean current variability and the influence of the Amazon and Orinoco freshwater plumes. Deep-Sea Research Part I: Oceanographic Research Papers 54, 1451-1473.

Clarke, K.R., Warwick, R.M., 2001. Change in Marine Communities - An Approach to Statistical Analysis and Interpretation, second ed. PRIMER-E, Plymouth.

Cooley, S.R., Yager, P.L., 2006. Physical and biological contributions to the western tropical North Atlantic Ocean carbon sink formed by the Amazon River plume. Journal of Geophysical Research 111, C08018.

Curtin, T.B., 1986. Physical observations in the plume region of the Amazon River during peak discharge - I. Water masses. Continental Shelf Research 6, 31-51.

Curtin, T.B., Legeckis, R.V., 1986. Physical observations in the plume region of the Amazon River during peak discharge - I. Surface variability. Continental Shelf Research 6, 31-51.

Del Vecchio, R., Subramaniam, A., 2004. Influence of the Amazon River on the surface optical properties of the western tropical North Atlantic Ocean. Journal of Geophysical Research 109, C11001.

DeMaster, D.J., 1996. Biogeochemical processes in Amazon shelf waters: chemical distributions and uptake rates of silicon, carbon and nitrogen. Continental Shelf Research 16, 617-643.

DeMaster, D.J., Pope, R.H., 1996. Nutrient dynamics in Amazon shelf waters: results from AMASSEDS. Continental Shelf Research 16, 263-289.

DeMaster, D.J., Knapp, G.B., Nittrouer, C.A., 1983. Biological uptake and accumulation of silica on the Amazon continental shelf. Geochimica et Cosmochimica Acta 47, 1713-1723.

DeMaster, D.J., Kuehl, S.A., Nittrouer, C.A., 1986. Effects of suspended sediments on geochemical processes near the mouth of the Amazon River: examination of biological silica uptake and the fate of particle-reactive elements. Continental Shelf Research 6, 107-125.

DeMaster, D.J., Smith Jr., W.O., Nelson, D.M., Aller, J.Y., 1996. Biogeochemical processes in Amazon shelf waters: chemical distributions and uptake rates of silicon, carbon and nitrogen. Continental Shelf Research 16, 617-643.

Dokulil, M., Skolaut, C., 1986. Succession of phytoplankton in a deep stratifying lake: Mondsee, Austria. Hydrobiologia 138, 9-24.

Foster, R.A., Subramaniam, A., Mahaffey, C., Carpenter, E.J., Capone, D.G., Zehr, J.P., 2007. Influence of the Amazon River plume on distributions of free-living and symbiotic cyanobacteria in the western tropical north Atlantic ocean. Limnology and Oceanography 52, 517-532.

Foster, R.A., Kuypers, M.M.M., Vagner, T., Paerl, R.W., Musat, N., Zehr, J.P., 2011. Nitrogen fixation and transfer in open ocean diatom-cyanobacterial symbioses. International Society for Microbial Ecology Journal 5, 1484-1493.

Gervais, F., 1997. Light-dependent growth, dark survival, and glucose uptake by cryptophytes isolated from a freshwater chemocline. Journal of Phycology 33, $18-25$.

Gibbs, R.J., 1972. Water chemistry of the Amazon River. Geochimica et Cosmochimica Acta 36, 1061-1066.

Gibbs, R.J., 1976a. Amazon River sediment transport in the Atlantic Ocean. Geology (Boulder) 4, 45.

Gibbs, R.J., 1976b. Amazon River sediment transport in the Atlantic Ocean. Geology $4,45-48$.

Goering, J.J., Dugdale, R.C., Menzel, D.W., 1966. Estimates of in situ Rates of Nitrogen Uptake by Trichodesmium sp. in the Tropical Atlantic Ocean. Limnology and Oceanography $11,614-620$.

Haxo, F.T., Fork, D.C., 1959. Photosynthetically active accessory pigments of Cryptomonads. Nature 198, 1051-1053.

Hellweger, F.L., Gordon, A.L., 2002. Tracing Amazon River water into the Caribbean Sea. Journal of Marine Research 60, 537-549.

Hu, C., Montgomery, E.T., Schmitt, R.W., Muller-Karger, F.E., 2004. The dispersal of the Amazon and Orinoco River water in the tropical Atlantic and Caribbean Sea: observation from space and S-PALACE floats. Deep Sea Research Part II: Topical Studies in Oceanography 51, 1151-1171.

Kirk, J.T.O., 1994. Light and Photosynthesis in the Sea. Cambridge University Press, United Kingdom, p. 511.

Knap, A., Michaels, A., Close, A., Ducklow, H., Dickson, A., 1994. Protocols for the Joint Global Ocean Flux Study (JGOFS) Core Measurements. JGOFS Report, 19, 170.

Lentz, S.J., 1995a. The Amazon River Plume during AMASSEDS: spatial characteristics and salinity variability. Journal of Geophysical Research 100, 2355.

Lentz, S.J., 1995b. Seasonal variations in the horizontal structure of the Amazon Plume inferred from historical hydrographic data. Journal of Geophysical Research 100, 2391.
Lewitus, A.J., Caron, D.A., 1991. Physiological responses of phytoflagellates to dissolved organic substrate additions. 2. Dominant role of autotrophic nutrition in Pyrenomonas salina (Cryptophyceae). Plant and Cell Physiology 32, 791-801.

MacIssac, E.A., Stockner, J.G., 1993. Enumeration of phototrophic picoplankton by autofluorescence microscopy. In: Kemp, P.F., Sherr, B.F., Sherr, E.B., Cole, J.J. (Eds.), Handbook of Methodology in Aquatic Microbial Ecology. Lewis Publishers, Boca Raton, Florida, USA, pp. 187-197.

McKee, B.A., DeMaster, D.J., Nittrouer, C.A., 1986. Temporal variability in the partitioning of thorium between dissolved and particulate phases on the Amazon shelf: implications for the scavenging of particle-reactive species. Continental Shelf Research 6, 87-106.

Mertes, L., 1993. Estimating suspended sediment concentrations in surface waters of the Amazon River wetlands from Landsat images. Remote Sensing of Environment 43, 281-301.

Molleri, G., Kampel, M., de Moraes Novo, E., 2010a. Spectral classification of water masses under the influence of the Amazon River plume. Acta Oceanologica Sinica 29, 1-8.

Molleri, G.S.F., Novo, E.M.L.d.M., Kampel, M., 2010b. Space-time variability of the Amazon River plume based on satellite ocean color. Continental Shelf Research $30,342-352$.

Müller-Karger, F.E., McClain, C.R., Fisher, T.R., Esaias, W.E., Varela, R., 1989. Pigment distribution in the Caribbean sea: observations from space. Progress in Oceanography 23, 23-64.

Nelson, D.M., Riedel, G.F., Millan-Nunez, R., Lara-Lara, J.R., 1984. Silicon uptake by algae with no known Si requirement. I. True cellular uptake and $\mathrm{pH}$ induced precipitation by Phaeodactylum tricornutum (Bacillariophyceae) and Platymonas sp. (Prasinophyceae). Journal of Phycology 20, 141-147.

Nittrouer, C.A., Curtin, T.B., DeMaster, D.J., 1986. Concentration and flux of suspended sediment on the Amazon continental shelf. Continental Shelf Research 6, 151-174.

Nittrouer, C.A., DeMaster, D.J., Figueiredo, A.G., Rine, J.M., 1991. AMASSEDS: An interdisciplinary investigation of a complex coastal environment. Oceanography (Washington, DC) 4, 3-7.

Qasim, S.Z., Bhattathiri, P.M.A., Devassy, V.P., 1972. The influence of salinity on the rate of photosynthesis and abundance of some tropical phytoplankton. Marine Biology 12, 200-206.

Richey, J.E., Nobre, C., Deser, C., 1989. Amazon river discharge and climate variability: 1903 to 1985 . Science 246, 101-103.

Santos, M.L., Muniz, K., Barros-Neto, B., Araujo, M., 2008. Nutrient and phytoplankton biomass in the Amazon River shelf waters. Anais da Academia Brasileira de Ciências (Annals of the Brazilian Academy of Sciences) 80, 703717.

Schultze-Lam, S., Harauz, G., Beveridge, T.J., 1992. Participation of a cyanobacterial S-layer in fine-grain mineral formation. Journal of Bacteriology 174, 79717981.

Shipe, R.F., Curtaz, J., Subramaniam, A., Carpenter, E.J., Capone, D.G., 2006. Diatom biomass and productivity in oceanic and plume-influenced waters of the western tropical Atlantic ocean. Deep Sea Research Part I: Oceanographic Research Papers 53, 1320-1334.

Smith Jr., W.O., DeMaster, D.J., 1996. Phytoplankton biomass and productivity in the Amazon River plume: correlation with seasonal river discharge. Continental Shelf Research 16, 291-319.

Smith, W.O., Russell, G.J., 1995. Phytoplankton biomass and nutrient distributions in the Amazon River plume: environmental correlates. Geo-Marine Letters 15, 195-198.

Subramaniam, A., Yager, P.L., Carpenter, E.J., Mahaffey, C., Bjorkman, K., Cooley, S. Kustka, A.B., Montoya, J.P., Sanudo-Wilhelmy, S.A., Shipe, R., Capone, D.G., 2008. Amazon River enhances diazotrophy and carbon sequestration in the tropical North Atlantic Ocean. Proceedings of the National Academy of Sciences of the United States of America 105, 10460-10465.

Teixeira, C., Tundisi, J., 1967. Primary production and phytoplankton in equatorial waters. Bulletin of Marine Science 17, 884-891.

Turner, R.E., 2003. Global patterns of dissolved N, P and Si in large rivers. Biogeochemistry 64, 297-317.

Wood, F.E.J., 1966. A phytoplankton study of the amazon region. Bulletin of Marine Science 16, 102-123.

Yeung, L.Y., Berelson, W.M., Young, E.D., Prokopenko, M.G., Rollins, N., Coles, V.J. Montoya, J.P., Carpenter, E.J., Steinberg, D.K., Foster, R.A., Capone, D.G., Yager, P.L., 2012. Impact of diatom-diazotroph associations on carbon export in the Amazon River plume. Geophysical Research Letters 39, L18609. 